\title{
Occupational stress and associated factors among college instructors in Eritrea: A cross-sectional study 2019
}

\author{
Nebay A. Tquabo ${ }^{1}$, Nahom K. Gebregziabher ${ }^{2}$, Isseyas E. Tesfaldet ${ }^{3}$, Hermela M. Misghina ${ }^{3}$, Tereza F. Russom ${ }^{3}$, Mikias D. Weldemariam ${ }^{3}$
}

\author{
AFFILIATION \\ 1 Department of Nursing, Orotta College of Medicine and Health Sciences, \\ Asmara, Eritrea \\ 2 Department of Community Medicine and Primary Health Care, Orotta \\ College of Medicine and Health Sciences, Asmara, Eritrea \\ 3 Ministry of Health, Asmara, Eritrea
}

CORRESPONDENCE TO

Nebay A. Tquabo. Department of Nursing, Orotta College of Medicine and

Popul. Med. 2021;3(March):9
Health Sciences, Mai Bela Avenue, Zoba Michael Street, PO Box No. 8566, Asmara, Eritrea. E-mail: nebaytecabo@gmail.com

\section{KEYWORDS}

stress, occupational stress, associated factors, college instructors, Eritrea

Received: 29 May 2020; Revised: 21 October 2020,

Accepted: 1 March 2021

https://doi.org/10.18332/popmed/133815

\begin{abstract}
INTRODUCTION Multiple reports have indicated that the prevalence of work-related stress is increasing among academics. This has been attributed to the expanding number of students, the need for efficiency in providing higher quality education, accountability to multiple stakeholders, internal and external factors, and problems in management and workplace communication systems. In spite of the growing realization of the importance of work-related stress, little is known about the subject in SubSaharan Africa. In this study, we investigated the prevalence of work-related stress and associated factors in colleges across Eritrea.

METHODS This study was a cross-sectional study performed in 2019 in Eritrea. Sample size for this study was calculated using single population proportion formula and simple random sampling technique was used to acquire the study participants. A structured closed-ended questionnaire was subsequently used to collect sociodemographic and other occupation related data. The University and College Union model stress questionnaire was used to assess stress among
\end{abstract}

the study participants. Statistical analysis was conducted using IBM SPSS Statistics version 23.

RESULTS Based on the UCU model stress questionnaire, the overall prevalence of stress among college faculty was found to be $49.2 \%$. When assessing the stress related factors, Pearson's correlation test showed participant's stress score was moderately correlated with demand $(r=0.37)$, control $(r=0.36)$ and relations ( $r=0.32)$ scores. However weak, the stress score had a statistically significant positive correlation with role, change, and the support domain scores.

CONCLUSIONS Work-related stress among faculty members was prevalent in the study setting, as it was found to affect almost half of the study participants. The factors affecting stress can be categorized into three broader domains: uncertainty of career prospect, role confusion and lack of resources.

ABBREVIATIONS HSE: Health and Safety Executive; UCU: University and College Union; OCMHS: Orrotta College of Medicine \& Health Sciences; HAC: Hamelmalo Agricultural College; COS: College of Sciences; COE: College of Engineering; CBSS: College of Business and Social Sciences; COE/TTI: College of Education (Teachers Training Institute)

\section{INTRODUCTION}

Stress is a psychological factor produced by a change in an environment that is perceived as challenging, threatening or damaging to a person's wellbeing ${ }^{1}$. It can lead to a variety of psychological responses, the most common of which is anxiety. The term stress is commonly used to describe feelings of tensions or exhaustion usually associated with work overload or overly demanding work ${ }^{2}$.

Stress was reported to be one of the ten leading causes of death in the world ${ }^{3}$. It can lead to the development of several physical and psychological problems. For instance, chronic stress is believed to affect the immune system by disrupting healthy immune responses, and it can also lead to depressive disorder ${ }^{4,5}$. Stress is so prevalent that it is estimated $74 \%$ of 
people have felt so stressed that they were overwhelmed or unable to cope at some point in their life .

Work-related stress can be defined as a harmful reaction to undue pressures and demands related to the job role ${ }^{6}$. Occupational stress is an inherent component of any work environment, which is sometimes necessary, but this does not justify its translation into any form of physical, psychological, or behavioral distress ${ }^{4,7}$. Occupational and organizational stress has been identified as a key risk factor for cardiovascular problems ${ }^{8}$. Occupational stress is also viewed as a chronic condition that requires an understanding of the condition, like its epidemiology, prior to exploring and setting protection, prevention, and intervention alternatives ${ }^{4,7}$. Circumstances that are believed to cause stress are events or conditions that are unpredictable or uncontrollable, uncertain, ambiguous or unfamiliar to the person, or situations involving conflict ${ }^{9}$. Occupational stress affects both the employee and the organization as a whole, as workers experiencing undue stress are prone to absenteeism, reduced job performance and poor communication ${ }^{7}$. The impact of work related stress and job performance remains controversial. Many researchers found that the relation between occupational stress and job performance to be inversely related ${ }^{9,10,11}$. While some argue that the occupational stress can improve the performance of an employee and the outcome of work ${ }^{12}$. Nothing, of course, should be taken away from the type of work to be carried. However, when it comes to the impact of stress on human's physical and mental wellbeing, it is hard to find disagreement ${ }^{13-15}$.

A recent study of academic employees found strong links between work intensity and long working hours with negative implications for work-life balance ${ }^{16}$. Research findings also demonstrate that the features that traditionally protected employees working in universities and colleges against work-related stress, such as job control and support, have gradually eroded, thus exacerbating the pressure experienced by employees ${ }^{17}$. The reasons for the increasing level of work-related stress among academics has been attributed to the expanding number of students, the need for efficiency in providing higher quality education, accountability to multiple stakeholders, internal and external factors, and problems in management and workplace communication systems ${ }^{18}$.

A study conducted among academic staff in Gondar University, Ethiopia, found the prevalence of work-related stress to be $60.4 \%$. This study also found smoking, high job demand, low job control and age as significant factors affecting stress ${ }^{19}$. Studies conducted in several universities of Nigeria have found very high stress levels among university lecturers ${ }^{20,21}$. Prevalence of stress among university lecturers in Zimbabwe was found be as high as $50 \%{ }^{22}$ and a prevalence rate of $30.1 \%$ was reported from a study conducted in Tanzania $^{23}$. The differences in the prevalence of stress across countries might relate to the different tools the studies used. Nonetheless, stress seems to be a major challenge to institutes of higher education in general.

Several factors like workload, student-related issues, research and career development, interpersonal relationship and administrative-related issues were the main stressors identified in another study at a Nigerian university ${ }^{24}$. In addition, a Ghanaian study identified delay or irregularity in salary payment, workload, inadequate monetary reward, subject matter load and long working hours as the main sources of stress among university lecturers ${ }^{25}$. Study on occupational stress of academic staff in South African higher education institutions reported work overload and work-life balance as the main players in ill health of academics ${ }^{26}$.

The magnitude of stress among the college instructors has never been studied in Eritrea. Hence, this study aims at assessing the prevalence of work-related stress among faculty members of the six colleges of the country. In addition, the study has attempted to identify the workenvironment related factors that are deemed to be important in causing stress in these colleges.

\section{METHODS}

\section{Study design}

This cross-sectional study was conducted in all the six colleges in Eritrea: Orotta College of Medicine and Health Science (OCMHS), Hamelmalo College of Agricultural Science (HAC), College of Science (COS), College of Engineering (COE), College of Education (COE/TTI), and Adikeih College of Business and Social Sciences (CBSS), between February and March 2019. All the colleges are public institutions governed under the National Board of Higher Education and Research Institute. They are the only institutions of higher learning in the entire country. Four of the colleges are located in the central region and the remaining two colleges are located in Debub region (CBSS) and Anseba Region (HAC). The study population comprised college instructors who were on active duty at the time of the study. Permission to conduct the study was obtained from the Department of Nursing, Orotta College of Medicine and Health Sciences. Permission to conduct the study was sought from each person in-charge in all the colleges. Participants of the study were briefed about the purpose of the study, and written informed consent was obtained from each participant. Confidentiality of the data was maintained as data were collected anonymously.

\section{Sample size and sampling method}

Sample size for this study was calculated using single population proportion formula $\left[\mathrm{n}_{1}=\mathrm{Z}^{2}(\mathrm{p} \times \mathrm{q}) / \mathrm{e}^{2}\right]$. The following parameters were used to reach the initial sample size $\left(\mathrm{n}_{1}\right): \mathrm{Z}=1.96$ for $95 \% \mathrm{CI}$, p (proportion) $=0.5(50 \%)$, $\mathrm{q}=1-0.5(0.5)$ and e (margin of error) $=0.05$. Based on this, $\mathrm{n}_{1}$ was 384.16. In order to adjust this number to the actual population size, we used the correction factor, i.e. $n_{2}=\left(n_{1} \times N\right) /$ $\left(\mathrm{n}_{1}+\mathrm{N}\right)$ where $\mathrm{N}$ (total population) $=429$. This gave a sample 
size $\left(n_{2}\right)$ of 202 . Finally, a $10 \%$ of the $n_{2}$ was added to the sample, for assumed non-response, to get the final sample size of 222. This study employed simple random sampling technique to acquire the study participants. First, the sample size was allocated to each college proportionally to the total number of academic staff. Then, a sampling frame was developed in each college from which participants were selected by using simple random sampling technique. In case the selected instructor was not available during the data collection time, we used replacement from those not selected using the same technique.

\section{Instruments and data collection}

A structured closed-ended questionnaire was used to collect sociodemographic and other occupation related data. The University and College Union model stress questionnaire ${ }^{27}$ was used to assess stress among the study participants. The UCU model stress questionnaire is approved by the University and College Union in the UK. This is a selfreport survey instrument that has been developed by HSE to help employers measure the key hazards within their organizations and compare their performance with national standards. The HSE Indicator Tool comprises 63 items within the six hazard categories each scoring 1-4. The reliability for this questionnaire is high as Cronbach's alpha of each hazard is as follows: role clarity 0.834 , demands 0.873 , control 0.864 , relationship stress 0.837 , management of change 0.819 , peer support 0.848 , and managerial support 0.897 . These six work-environment related domains assessed as factors causing stress that include: Demands (include workload, pace of work and working hours); Control (measures levels of autonomy over working methods, as well as pacing and timing); Managerial Support (reflects supportive behaviors from line managers and the organization itself, such as the availability of feedback and encouragement); Relationships (assess levels of interpersonal conflict within the workplace, including bullying behavior and harassment); Role (examines levels of role clarity and the extent to which employees believe that their work fits into the aims of the department and the organization in general); and Change (reflects how effectively organizational changes are managed and communicated $)^{27}$.

\section{Statistical analysis}

After data collection, each questionnaire was checked for completeness and a code was given before data entry. Data was analyzed using SPSS version 20. Descriptive statistics such as frequencies, percentages, as well as chi-squared test were used to analyze the data. Bivariate correlation analysis, using Pearson's correlation was used to assess the association between the participants' score on the stress and hazard domain scores. $P$ values $\leq 0.05$ were taken as statistically significant.

\section{RESULTS}

\section{Demographic data}

A total of two hundred and twenty-two (222) questionnaires were distributed. Nine participants fail to return the questionnaire (response rate of 96\%). Of the 213 respondents, most (60\%) were lecturers, followed by senior lecturers (27.23\%). Most of the participants were permanent employees (63.4\%), male (89.2\%), and national staff (61\%). Majority (38\%) of the study subjects were aged 26-35 years followed by $36-45$ years (33.3\%). The distribution of instructors according college home base was as follows: $19.2 \%$ were from CBSS, $17.8 \%$ from OMCHS, $17.8 \%$ were from COS, $18.8 \%$ were from COE/TTI, $7.5 \%$ were from COE, and $18.8 \%$ were from HCAS. The work load of the participants was assessed in terms of number of hours they work per week. As such, most (28.2\%) of the participants reported that they work between 36-40 hours per week, followed by 41-45 hours per week (22.5\%). Part-time instructors and national staff had statistically significant higher proportion of stress compared to their counterparts. In addition, collegewise distribution of stress proportions had a statistically significant difference. However, the remaining variables showed no significant difference in stress proportion (Table 1). The frequency of stress related symptoms the participants experienced while working was assessed as: never, sometimes, or often. Most of the participants reported that they have experienced feelings of irritation (70.4\%), anger (69\%), frustration $(58.2 \%)$, helplessness (37.1\%), anxiety

Table 1. Chi-squared analysis between sociodemographic characteristics of the participants and stress, Eritrea, $2019(\mathrm{~N}=213)$

\begin{tabular}{|c|c|c|c|c|}
\hline \multirow[t]{2}{*}{ Variables } & \multicolumn{2}{|c|}{ Prevalence of stress } & \multirow{2}{*}{$\begin{array}{l}\text { Total } \\
\text { n (\%) }\end{array}$} & \multirow[t]{2}{*}{$\chi^{2}$} \\
\hline & $\begin{array}{c}\text { No } \\
\text { n (\%) }\end{array}$ & $\begin{array}{c}\text { Yes } \\
\text { n (\%) }\end{array}$ & & \\
\hline Total & $108(50.7)$ & 105 (49.3) & $213(100)$ & \\
\hline \multicolumn{5}{|l|}{ Position/staff grade } \\
\hline Lecturer & $65(50.8)$ & $63(49.2)$ & $128(60.0)$ & \multirow{3}{*}{$6.81^{*}$} \\
\hline Part-timer lecturer & $3(20)$ & $12(80)$ & $15(7.04)$ & \\
\hline Senior lecturer & $40(57.1)$ & $30(42.9)$ & $70(27.23)$ & \\
\hline
\end{tabular}


Table 1. Continued

\begin{tabular}{|c|c|c|c|c|}
\hline \multirow[t]{2}{*}{ Variables } & \multicolumn{2}{|c|}{ Prevalence of stress } & \multirow{2}{*}{$\begin{array}{l}\text { Total } \\
\text { n (\%) }\end{array}$} & \multirow[t]{2}{*}{$\chi^{2}$} \\
\hline & $\begin{array}{c}\text { No } \\
\text { n (\%) }\end{array}$ & $\begin{array}{c}\text { Yes } \\
\text { n (\%) }\end{array}$ & & \\
\hline \multicolumn{5}{|l|}{ Post type } \\
\hline Permanent & $68(50.4)$ & $67(49.6)$ & $135(63.4)$ & \multirow{2}{*}{0.016} \\
\hline Temporary & $49(51.3)$ & 38 (48.7) & $78(36.6)$ & \\
\hline \multicolumn{5}{|l|}{ Gender } \\
\hline Male & $98(51.6)$ & $92(52.5)$ & $190(89.2)$ & \multirow{2}{*}{0.53} \\
\hline Female & $10(43.5)$ & $13(56.5)$ & 23 (10.7) & \\
\hline \multicolumn{5}{|l|}{ Nationality } \\
\hline Expatriate & $50(60.2)$ & $33(39.8)$ & $83(38.9)$ & \multirow{2}{*}{$4.94^{*}$} \\
\hline National staff & $58(44.6)$ & $72(55.4)$ & $130(61.0)$ & \\
\hline \multicolumn{5}{|l|}{ Age (years) } \\
\hline$\leq 35$ & $49(57)$ & $37(43)$ & $86(38.0)$ & \multirow{4}{*}{4.47} \\
\hline $36-45$ & $35(49.3)$ & $36(50.7)$ & $71(33.3)$ & \\
\hline $46-55$ & $10(34.5)$ & $19(65.5)$ & $29(13.6)$ & \\
\hline$\geq 56$ & $14(51.9)$ & $13(48.1)$ & $27(12.7)$ & \\
\hline \multicolumn{5}{|l|}{ Colleges } \\
\hline CBSS & $32(78)$ & $9(22)$ & $41(19.2)$ & \multirow{6}{*}{$26.07^{* *}$} \\
\hline OCMHS & $23(34.2)$ & $25(65.8)$ & $38(17.8)$ & \\
\hline $\cos$ & $17(44.7)$ & $21(55.3)$ & $38(17.8)$ & \\
\hline COE/TTI & $24(60)$ & $16(40)$ & $40(18.8)$ & \\
\hline $\mathrm{COE}$ & $10(62.5)$ & $6(37.5)$ & $16(7.5)$ & \\
\hline HAC & $12(30)$ & $28(70)$ & $40(18.8)$ & \\
\hline \multicolumn{5}{|c|}{ Workload in hours/week $(n=213)$} \\
\hline $30-35$ & $24(63.2)$ & $14(36.8)$ & $38(17.8)$ & \multirow{5}{*}{7.27} \\
\hline $36-40$ & $34(56.7)$ & $26(43.3)$ & $60(28.2)$ & \\
\hline $41-45$ & $24(50.0)$ & $24(50.0)$ & $48(22.5)$ & \\
\hline $46-50$ & 15 (41.7) & $21(58.3)$ & $36(16.9)$ & \\
\hline$\geq 51$ & $11(35.5)$ & $20(64.5)$ & $1(0.04)$ & \\
\hline
\end{tabular}

${ }^{*} \mathrm{p}<0.05,{ }^{* *} \mathrm{p}<0.001$.

(57.7\%), depression (37.6\%), inattention (47.5) and overtired (68.6\%), to a varying degree (Table 2$)$.

The six hazard domains of the UCU model comprised 63 items. However, the researchers tried to extract and present the items reported as 'stressful' by $>20 \%$ of the participants and/or variables reported as 'very stressful' by $>10 \%$ of the study participants. Accordingly, within the demand domain 'increased workload' was mentioned as stressful and very stressful by $29.6 \%$ and $8.0 \%$ of the participants, respectively. Lack of funds or resources accounted for $27.7 \%$ stressful and $14.6 \%$ very stressful in the domain of control. Within the relationship domain, bullying behavior from managers/staff/ students was stressful for $15.5 \%$ and very stressful $8 \%$. From variables within the role domain, lack of career development opportunities was mentioned as stressful and very stressful by $22.5 \%$ and $20.2 \%$ of the participants, respectively. Within
Table 2. Prevalence of stress symptoms among college instructors, Eritrea, $2019(\mathrm{~N}=213)$

\begin{tabular}{lrcc} 
Stress symptoms & \multicolumn{1}{c}{$\begin{array}{c}\text { Never } \\
\mathbf{n}(\%)\end{array}$} & $\begin{array}{c}\text { Sometimes } \\
\mathbf{n}(\%)\end{array}$ & $\begin{array}{c}\text { Often } \\
\mathbf{n}(\%)\end{array}$ \\
\hline Irritated & $63(29.6)$ & $135(63.4)$ & $15(7.0)$ \\
Angry & $66(31.0)$ & $137(64.3)$ & $10(4.7)$ \\
Frustrated & $89(41.8)$ & $114(53.5)$ & $10(4.7)$ \\
Helpless & $134(62.9)$ & $65(30.5)$ & $14(6.6)$ \\
Anxious & $90(42.3)$ & $108(50.7)$ & $15(7.0)$ \\
Depressed & $133(62.4)$ & $73(34.3)$ & $7(3.3)$ \\
Inattention & $112(52.6)$ & $90(42.3)$ & $11(5.2)$ \\
Overtired & $67(31.5)$ & $113(53.1)$ & $33(15.5)$
\end{tabular}


Table 3. Factors causing stress among college instructors, Eritrea, $2019(\mathrm{~N}=213)$

\begin{tabular}{|c|c|c|c|c|}
\hline Variables & $\begin{array}{c}\text { Not applicable } \\
\text { n (\%) }\end{array}$ & $\begin{array}{c}\text { Occasionally } \\
\text { stressful } \\
\text { n (\%) }\end{array}$ & $\begin{array}{l}\text { Stressful } \\
\text { n (\%) }\end{array}$ & $\begin{array}{l}\text { Very stressful } \\
\text { n (\%) }\end{array}$ \\
\hline \multicolumn{5}{|l|}{ Demand } \\
\hline Larger classes & $59(27.7)$ & $97(45.5)$ & $46(21.6)$ & $11(5.2)$ \\
\hline Teaching new courses & $45(21.1)$ & $99(46.5)$ & $61(28.6)$ & $8(3.8)$ \\
\hline Administration & $60(28.2)$ & $78(36.6)$ & $48(22.5)$ & 27 (12.7) \\
\hline Increased workload & $36(16.9)$ & $97(45.5)$ & $63(29.6)$ & $17(8.0)$ \\
\hline Traveling time & $64(30.0)$ & $80(37.6)$ & $45(21.2)$ & $24(11.3)$ \\
\hline \multicolumn{5}{|l|}{ Control } \\
\hline Lack of funds/resources & $45(21.1)$ & $78(36.6)$ & $59(27.7)$ & $31(14.6)$ \\
\hline $\begin{array}{l}\text { Given responsibility without the authority to take } \\
\text { decisions }\end{array}$ & $62(29.1)$ & $74(34.7)$ & $52(24.4)$ & $25(11.7)$ \\
\hline Insufficient time for scholarship and/or research & $58(27.2)$ & $69(32.4)$ & $50(23.5)$ & $36(16.9)$ \\
\hline \multicolumn{5}{|l|}{ Relationship } \\
\hline Bullying behavior from managers/staff/students & $100(46.9)$ & $63(29.6)$ & $33(15.5)$ & $17(8.0)$ \\
\hline Dealing with conflict situations & $66(31.0)$ & $101(47.4)$ & $32(15.0)$ & $14(6.6)$ \\
\hline Lack of line management support & $69(32.4)$ & $96(45.1)$ & $33(15.5)$ & $15(7.0)$ \\
\hline \multicolumn{5}{|l|}{ Role } \\
\hline Unclear job description & $103(48.4)$ & $50(23.5)$ & $34(16.0)$ & $26(12.2)$ \\
\hline Lack of promotion prospects & $39(18.3)$ & $83(39.0)$ & $47(22.1)$ & $44(20.7)$ \\
\hline Lack of career development opportunities & $59(27.7)$ & $63(29.6)$ & $48(22.5)$ & $43(20.2)$ \\
\hline Poor pay prospects & $83(39.0)$ & $42(19.7)$ & $46(21.6)$ & $42(19.7)$ \\
\hline \multicolumn{5}{|l|}{ Change } \\
\hline $\begin{array}{l}\text { High degree of uncertainty due to restructuring and } \\
\text { redundancies }\end{array}$ & $72(33.8)$ & $77(36.2)$ & $40(18.8)$ & $24(11.3)$ \\
\hline Changes without consultation & $49(23.0)$ & $91(42.7)$ & $52(24.4)$ & $21(9.9)$ \\
\hline Lack of participation in decision making & $56(26.3)$ & $88(41.3)$ & $48(22.5)$ & $21(9.9)$ \\
\hline \multicolumn{5}{|l|}{ Managerial support } \\
\hline Lack of information about what is going on & $46(21.6)$ & $76(35.7)$ & $58(27.2)$ & $33(15.5)$ \\
\hline Insufficient admin support & $42(19.7)$ & $88(41.3)$ & $60(28.2)$ & $23(10.8)$ \\
\hline Lack of funds/resources to do the job & $49(23.0)$ & $85(39.9)$ & $48(22.5)$ & $31(14.6)$ \\
\hline Lack of facilities & $45(21.1)$ & $84(39.4)$ & $48(22.5)$ & $36(16.9)$ \\
\hline
\end{tabular}

Table 4. Correlations of the stress score with UCU domain scores among college instructors, Eritrea, 2019 $(\mathrm{N}=213)$

\begin{tabular}{llc}
\hline Variables & Mean \pm SD & $r$ \\
\hline Stress score & $39.67 \pm 6.33$ & \\
Demand score & $33.00 \pm 7.31$ & $0.373^{* *}$ \\
Control score & $18.21 \pm 4.71$ & $0.368^{* *}$ \\
Relation score & $16.58 \pm 5.11$ & $0.323^{* *}$ \\
Role score & $16.69 \pm 5.09$ & $0.256^{* *}$ \\
Change score & $19.20 \pm 5.52$ & $0.235^{* *}$ \\
Support score & $19.56 \pm 5.51$ & $0.254^{* *}$
\end{tabular}

**Correlation is significant at the 0.01 level (2-tailed). the change domain, 'changes without consultation' were a major stress factor; $24.4 \%$ and $9.9 \%$ of the participants responded as stressful and very stressful, respectively. From variables within the managerial support domain, 'lack of information about what is going on' was mentioned by $27.2 \%$ and $15.5 \%$ of study participants as stressful and very stressful, respectively (Table 3 ).

Pearson's correlation test was used to assess the correlation between participants stress score and their score in the six stress domains measured. Based on the results, participant's stress score was moderately correlated with demand $(\mathrm{r}=0.37)$, control $(\mathrm{r}=0.36)$ and relations $(\mathrm{r}=0.32)$ scores. However weak, the stress score had statistically significant positive correlation with role, change and support domains scores (Table 4). 


\section{DISCUSSION}

This study aimed at assessing the prevalence of stress and factors influencing it among faculty of higher education institutions of Eritrea. Based on the UCU model stress questionnaire, the overall prevalence of stress among college faculty was found to be $49.2 \%$. This finding is much higher than reports from Malaysia $21.7 \%^{15}$ and Tanzania $30.1 \%{ }^{23}$. However, higher prevalence rate (54.06\%) was reported from a study of teachers at a national key comprehensive university in $\mathrm{China}^{28}$. The difference in prevalence of stress among these studies could be due to the inherent difference in the nature of the settings or the instrument used to assess stress. For instance, we used the UCU model stress questionnaire while the Chinese study used the 10 -item Kessler Psychological Distress Scale ${ }^{28}$. The extent of stress observed in this study is alarming as it affects the instructors' performance and the teaching and learning process of the colleges $^{29,30}$ and can compromise the quality of education. On the other hand, there is evidence that the increment in stress level of the participants at work had direct relation with the increment in their job performance ${ }^{12}$.

Most (70.4\%) of the participants reported that they have experienced feelings of irritation. This finding was slightly higher than the results reported from a study done in West Visayas State University, Philippines, where feelings of irritability were reported by $58 \%$ of the participants ${ }^{27}$. In this study, almost two-thirds of the college instructors reported to have experienced frustration, and feeling of anger was reported by $69 \%$ of the participants. Frustration with the work environment, as stressor, was reported by $20 \%$ of participants in the Philippines ${ }^{31}$. Helplessness was reported by $37.1 \%$ of study participants while anxiety was reported by $57.7 \%$ of the teachers. In the Tanzanian study, where participants were drawn from two public and two private universities, $12.9 \%$ of the respondents were reported to have experienced helplessness ${ }^{23}$. Feelings of depression were prevalent as $37.6 \%$ of the participants reported to have experienced it while working. Higher rate (58.9\%) of depression was reported by a Chinese university teachers' study, which used a Chinese version of the Center for Epidemiologic Studies Depression Scale ${ }^{32}$. Inattention while working affected $47.5 \%$ of the study participants and, $68.6 \%$ of the study group reported to be overtired. Similar findings were reported from a study conducted in Solusi University, Zimbabwe, where lack of concentration and exhaustion were found to affect $62.5 \%$ and $83.3 \%$ of the study participants ${ }^{22}$. All these findings show that stress symptoms are prevalent among instructors in higher learning institutes and mainly indicate the existence of psychological problems ${ }^{33}$. Hence, this calls for immediate intervention to alleviate and manage work-related stress among college faculty, as unattended chronic stress will affect the overall health of the body ${ }^{34}$.

The factors presumed to cause stress among college faculty members, according to UCU, are categorized into six domains. Each domain contains several variables however; we selected the variables found to have higher proportions in each domain as significant for discussion. In the 'demand' domain, which assesses areas like workload, pace of work and working hours, five variables were identified as important stressors in this setting. These include teaching larger classes, teaching new courses, administration, increased workload, and traveling time. In the current study, faculty members stress score was found to be moderately positively correlated with demand domain score. A study conducted in India regarding stress among college teachers revealed similar findings with $47.5 \%$ of the respondents reporting feeling stressed due to organizational environment stress $^{35}$. These findings indicate that the amount of time a staff member is required to spend on job related activities, in or out of the college, creates more stress.

The control domain assessed the levels of autonomy the faculty members have over work methods. Bivariate correlation analysis has shown a statistically significant correlation between stress and control domain scores. The variables identified as significant stressors in the current study setting were: given responsibility without authority to make decisions, lack of funds or resources, insufficient time for scholarship and/or research. This was steady with the research done in Zimbabwe: lack of funds and support to do the job, given responsibility without the authority to take decisions, and insufficient time for scholarship and/or research proved to be the stressors to the respondents ${ }^{22}$. A study conducted among university teachers in India reported that $27.8 \%$ of the teachers did not have full autonomy over their work environment and further explained that they are not even involved in decision-making affecting their job ${ }^{36}$.

The levels of interpersonal conflict within the workplace, including bullying behavior and harassment, as causes of stress were assessed in the 'relationship' domain. The current study showed that bullying behavior from managers, staff or students, dealing with conflict situations and lack of line management support as important stressors. In addition, participants score in the relationship domain was significantly correlated with their stress score. Several studies have reported the relationship between problem in workplace interpersonal relationships and work-related stress symptoms $s^{11,37,38}$. Naima et al. ${ }^{39}$ found a positive correlation between bullying and work stress symptoms.

The role domain assessed the levels of role clarity the faculty members have and the extent to which they believe that their work fits into the aims of the institution in which they are working. Unclear job descriptions, lack of promotion prospect, lack of carrier development opportunities and poor pay prospects were the key stressors identified in the current study. Role ambiguity is reported to be one of the causes of stress among Pakistan university teachers ${ }^{40}$. A study done in India identified issues of role and personal development as organizational stressors among working women ${ }^{41}$. Furthermore, Michie ${ }^{9}$ identified role ambiguity and problems in career development, like lack of job security, as stressors 
intrinsic to the job. In our study, having higher scores in the role domain was associated with higher stress scores.

Within the 'change' domain, which reflects how effectively organizational changes are managed and communicated, high degree of uncertainty due to restructuring and redundancies, changes without consultation, and lack of participation in decision-making were deemed to be highly stressful. Similarly, the correlation analysis showed a statistically significant positive correlation between stress and change domain scores. Similar findings were reported in a study conducted in Russia where instability and uncertainty of organizational changes were identified as causes of stress, innovation fatigue, and emotional burnout ${ }^{42}$. Likewise, a study on Hong Kong teachers revealed employees experience stress during an acknowledged period of organizational uncertainty ${ }^{43}$. The significance of teachers' participation on decision making, for enhancing their organizational roles as professional decision makers, has been emphasized as lack of participation, is expected to result in negative outcomes including stress ${ }^{44}$.

Managerial support was the last domain assessed in this study and lack of information about what is going on, insufficient administration support, lack of funds or resources to do the job and lack of facilities, were found to be significant factors causing stress in the study participants. The participants score in this domain was weakly positive but there was statistically significant correlation with their stress score. Insufficient funding and resources were identified as a work-related stressor in a qualitative study of 178 academic and general staff from 15 Australian universities ${ }^{45}$. A study conducted by Crosby ${ }^{46}$ found a strong relationship between administrative support and staff burnout, and recommended maintaining strong school-level administrative support.

\section{Strengths and limitations}

This study is the first of its kind to assess the level of stress among instructors of higher learning institutions and the factors influencing it in Eritrea. Hence, it will have theoretical implications for researchers interested in this area, and practical implications for decision makers. The fact that this study included faculty members from all institutions of higher education in the country is one of its strengths. In addition, the use of UCU model to assess the workrelated stressors was another significant strength as it was comprehensive in covering a wide range of stressors in the work environment. However, this study has some limitations. First, it only assessed the work-related factors, but personal factors, which might be important in determining the person's reaction to stressors, were not assessed. Second, the factors identified are presumptive, as they were assessed objectively as reported by the study participants. The effect of stress on the instructors' health, performance and impact on the job, were not investigated. Therefore, the results of this study should be taken as general indicators of the current situation.

\section{CONCLUSIONS}

Work-related stress is prevalent in this study setting, as it was found to affect almost half of the study participants. This high prevalence can be in part attributed to the fact that the study was undertaken during a time of massive organizational changes in the institutions of higher learning of the country. Nonetheless, the responsible bodies should take a step to further understand and manage the situation, as this might affect the quality of education given in these colleges. Most of the factors found to have affected the college instructors are related to the organizational setting, mainly related to lack of conducive environment for the faculty to carry out their job without difficulty. The factors affecting stress in this study setting can be categorized into three broader domains: uncertainty of career prospects, role confusion, and lack of resources.

This study has found the work conditions in these colleges as stressful, which is in line with the theoretical stands that identify institutes of higher learning as a source occupational stress. Further rigorous quantitative and qualitative research is needed to investigate the determinants of stress and its impact on the faculty performance, however. Furthermore, the magnitude of stress observed in this study calls for action to curb the effects of stress both on the faculty and the quality of education they provide. This requires organizational adjustments, by involving the faculty, to make the work environment more conducive to better academic performance. In addition, the implementation of early screening tests to detect the stress level of instructors at college level could help in tackling the problem.

\section{REFERENCES}

1. Selye H. Stress of life. McGraw-Hill; 1956.

2. Varcarolis EM. Understanding Anxiety and Anxiety Defenses. In: Varcarolis EM, Carson VB, Shoemaker NC, Halter MJ, Varcarolid EM, eds. Foundations of Psychiatric Mental Health Nursing: A Clinical Approach. 5th ed. Elsevier Saunders; 2006.

3. Quick JC, Cooper CL. Stress and Strain. 2nd ed. Health Press; 2003:75.

4. Mental Health Foundation. Stress: Are we coping? Published May 2018. Accessed October 21, 2020. https://www. mentalhealth.org.uk/sites/default/files/stress-are-wecoping.pdf

5. Krantz DS, Whittaker KS, Sheps DS. Psychosocial risk factors for coronary heart disease: Pathophysiologic mechanisms. In: Allan R, Fisher J, eds. Heart and mind: The practice of cardiac psychology. 2nd ed. American Psychological Association; 2011:91-113. doi:10.1037/13086-004

6. Kinman G, Wray S. 2014. Work-related wellbeing in UK Higher Education - 2014. University and College Union (UCU). Published August 30, 2017. Accessed October 21, 2020. https://core.ac.uk/download/pdf/130975051.pdf

7. Quick JC, Henderson DF. Occupational Stress: Preventing Suffering, Enhancing Wellbeing. Int J Environ Res Public 
Health. 2016;13(5):459. doi:10.3390/ijerph13050459

8. Schnall PL, Dobson M, Landsbergis P. Work, Stress, and Cardiovascular Disease. In: Cooper CL, Quick JC, eds. The Handbook of Stress and Health: A Guide to Research and Practice. Wiley Blackwell; 2017:99-124. Accessed October 21, 2020. https://onlinelibrary.wiley.com/doi/ pdf/10.1002/9781118993811.ch6

9. Michie S. Causes and management of stress at work. Occup Environ Med. 2002;59(1):67-72. doi:10.1136/oem.59.1.67

10. Parveen H, Bano M. Relationship Between Teachers' Stress and Job Satisfaction: Moderating Role of Teachers' Emotions. Pakistan journal of psychological research : PJPR. 2019;34(2):353-366. doi:10.33824/PJPR.2019.34.2.19

11. Blix AG, Cruise RJ, Mitchell BM, Blix GG. Occupational stress among university teachers. Educational Research. 1994;36(2):157-169. doi:10.1080/0013188940360205

12. Amoako EP, Gyamfi OA, Emmanuel AK, David B. The Effect of Occupational Stress on Job Performance at Aspet A. Company Limited. Global Journal of Arts, Humanities and Social Sciences. 2017;5(8):1-17. Accessed October 21, 2020. http://www.eajournals.org/wp-content/uploads/The-Effectof-Occupational-Stress-on-Job-Performance-at-Aspet-A.Company-Limited.pdf

13. Rakshit M, Sharma Y. Occupational Stress and its impact on Physical and Psychological Health of Employees in Private Educational Organizations: Management Strategies. International Journal of Advanced Research in Education \& Technology (IJARET). 2016;3(3):96-101. Accessed October 21, 2020. http://ijaret.com/wp-content/themes/felicity/ issues/vol3issue3/madhu.pdf

14. Li Y, Sun X, Ge H, Liu J, Chen L. The Status of Occupational Stress and Its Influence the Quality of Life of Copper-Nickel Miners in Xinjiang, China. Int J Environ Res Public Health. 2019;16(3):353. doi:10.3390/ijerph16030353

15. Mukosolu O, Ibrahim F, Rampal L, Ibrahim N. Prevalence of Job stress and its Associated Factors among University Putra Malaysia Staff. Malaysian journal of medicine and health sciences. 2015;11(1):27-38. Accessed October 21, 2020. https://medic.upm.edu.my/upload/dokumen/FKUSK1_ Article_4_(1).pdf

16. Hogan JM, Carlson JG, Dua J. Stressors and Stress Reactions Among University Personnel. Int J Stress Manag. 2002;9(4):289-310. doi:10.1023/A:1019982316327

17. Kinman G, Wray S. Taking its toll: rising stress levels in further education: UCU Stress Survey 2014. University and College Union; 2014. Accessed October 21, 2020. https:// www.ucu.org.uk/media/7264/UCU-stress-survey-2014/ pdf/ucu_festressreport14.pdf

18. Brennan J, Shah T, eds. Higher Education and Society in Changing Times: looking back and looking forward. Springer; 2011. Accessed October 21, 2020. https://scholar.harvard. edu/files/manja_klemencic/files/brennan_and_shah_2011_ cheri_lookingbackandlookingforward.pdf?m=1444558530

19. Kabito GG, Wami SD, Chercos DH, Mekonnen TH. Workrelated Stress and Associated Factors among Academic
Staffs at the University of Gondar, Northwest Ethiopia: An Institution-based Cross-sectional Study. Ethiop J Health Sci. 2020;30(2):223-232. doi:10.4314/ejhs.v30i2.10

20. Adebiyi DR. OCCUPATIONAL STRESS AMONG ACADEMIC STAFF OF EKITI STATE UNIVERSITY, ADO-EKITI. Eur Sci J. 2013;9(4):202-208. doi:10.19044/esj.2013.v9n4p\%25p

21. Ofoegbu F, Nwadiani M. Level of Perceived Stress Among Lectures in Nigerian Universities. Journal of Instructional Psychology. 2006;33(1):66-74. Accessed October 21, 2020. http://web.a.ebscohost.com/ehost/pdfviewer/ pdfviewer?vid=1\&sid=35237112 -f4fd-43b3-ac5d77c6ce1fa50d\%40sessionmgr4007

22. Masuku S, Muchemwa S. Occupational Stress among University Lecturers: A Case of Zimbabwe. USChina Education Review A. 2015;5(4):258-266. doi:10.17265/2161-623X/2015.04.003

23. Mkumbo K. Prevalence of and Factors Associated with Work Stress in Academia in Tanzania. International Journal of Higher Education. 2014;3(1):1-11. doi:10.5430/ijhe.v3n1p1

24. Akinmayowa JT, Kadiri PA. Stress Among Academic Staff in a Nigerian University. Covenant Journal of Business and Social Sciences (CJBSS). 2014;65(1):73-91. Accessed October 21, 2020. https://journals.covenantuniversity.edu.ng/index.php/ cjbss/article/download/18/14

25. Danku LS, Dzomeku VM, Dodor CT, Adade TC. STRESS AMONG PRIVATE UNIVERSITY LECTURERS IN GHANA: CAUSES AND COPING STRATEGIES. EPRA International Journal of Economic and Business Review. 2017;5(1):95101. Accessed October 21, 2020. https://eprapublishing. com//admin/admin/public/uploads/701pm13.Danku,\%20 Lydia \% 20 Sylvia, \% 20 D zomeku, \% 20 Veronica \% 20 Millicent,\%20Dodor,\%20Christian\%20Thywill\%20\&\%20 Adade,\%20Thomas\%20Clarkson.pdf

26. Barkhuizen N, Rothmann S. Occupational Stress of Academic Staff in South African Higher Education Institutions. S Afr J Psychol. 2008;38(2):321-336. doi:10.1177/008124630803800205

27. Court S, Kinman G. Tackling Stress in further education. University and College Union; 2009. Accessed October 21, 2020. https://www.ucu.org.uk/media/3022/Tackling-stressin-further-education-UCU-survey-findings-Dec-08/pdf/ucu_ festress_dec08.pdf

28. Li W, Kou C. Prevalence and correlates of psychological stress among teachers at a national key comprehensive university in China. Int J Occup Environ Health. 2018;24(1-2):7-16. doi :10.1080/10773525.2018.1500803

29. Sabagh Z, Hall NC, Saroyan A. Antecedents, correlates and consequences of faculty burnout. Educational Research. 2018;60(2):131-156. doi:10.1080/00131881.2018.1461573

30. Meng Q Wang G. A research on sources of university faculty occupational stress: a Chinese case study. Psychol Res Behav Manag. 2018;11:597-605. doi:10.2147/PRBM.S187295

31. Colacion-Quiros H, Gemora RB. Causes and Effects of Stress Among Faculty Members in a State University. Asia Pacific Journal of Multidisciplinary Research. 2016;4(1):18-27. 
Accessed October 21, 2020. http://www.apjmr.com/wpcontent/uploads/2016/03/APJMR-2016.4.1.04.pdf

32. Shen X, Yang YL, Wang Y, Liu L, Wang S, Wang L. The association between occupational stress and depressive symptoms and the mediating role of psychological capital among Chinese university teachers: a cross-sectional study. BMC Psychiatry. 2014;14:329. doi:10.1186/s12888-0140329-1

33. Tai KL, Ng YG, Lim PY. Systematic review on the prevalence of illness and stress and their associated risk factors among educators in Malaysia. PLoS One. 2019;14(5):e0217430. doi:10.1371/journal.pone.0217430

34. Mariotti A. The effects of chronic stress on health: new insights into the molecular mechanisms of brainbody communication. Future Sci OA. 2015;1(3):FSO23. doi:10.4155/fso.15.21

35. Sindhu KP. A Study on Stressors among College Teachers. IOSR Journal of Business and Management (IOSR-JBM). 2014;16(7, version III):37-41. doi:10.9790/487X-16733741

36. Kang LS, Sidhu H. Identification of Stressors at Work: A Study of University Teachers in India. Global Business Review. 2015;16(2):303-320. doi:10.1177/0972150914564421

37. Ivancevich JM, Matteson MT. Stress and work: A managerial perspective. Scott Foresman; 1980.

38. Jenitta JN, Mangaleswaran T. Factors Affecting the Stress of Teachers; A Special Reference to Trincomalee District. International Journal of Engineering Science and Computing. 2016;6(9):2328-2333. Accessed October 21, 2020. https:// ijesc.org/upload/d36ab6f124c7c24d01ef133b0a2df95f. Factors $\% 20$ Affecting $\% 20$ the $\% 20$ Stress $\% 20$ of $\% 20$ Teachers; $\% 20$ A $\% 20$ Special\%20Reference $\% 20$ to $\% 20$ Trincomalee\%20District.pdf

39. Malik NA, Björkqvist K, Österman K. Factors Associated with Occupational Stress among University Teachers in Pakistan and Finland. Journal of educational, health and community psychology. 2017;6(2). Accessed October 21, 2020. http://journal.uad.ac.id/index.php/Psychology/article/ download/7047/3603

40. Bhatti N, Hashmi MA, Raza SA, Shaikh FM, Shafiq K. Empirical Analysis of Job Stress on Job Satisfaction among University Teachers in Pakistan. International Business Research. 2011;4(3):264-270. doi:10.5539/ibr.v4n3p264

41. Tharakan PNO. Occupational stress and job satisfaction among working women. Journal of the Indian Academy of

\section{ACKNOWLEDGEMENTS}

We would like to extend our deep appreciation to the ethical committee of the Department of Nursing, Orotta College of Medicine and Health Sciences and National Board of Higher Education and Research Institute of Eritrea for their support to conduct the research. Furthermore, our sincere gratitude goes to the study participants and all who contributed to the work.

\section{CONFLICTS OF INTEREST}

The authors have completed and submitted the ICMJE Form for Disclosure of Potential Conflicts of Interest and none was reported.
Applied Psychology : JIAAP. 1992;18(1-2):37-40.

42. Barabanshchikova VV, Meshkova RP, Surova ND. Comparison of Stress Level among School Teachers in the Period of Organizational Changes. Procedia Soc Behav Sci. 2014;146(2014):375-380. doi:10.1016/j.sbspro.2014.08.131

43. Hassard J, Teoh K, Cox T. Organizational uncertainty and stress among teachers in Hong Kong: work characteristics and organizational justice. Health promot Int. 2017;32(5):860-870. doi:10.1093/heapro/daw018

44. Conley S. Chapter 6: Review of Research on Teacher Participation in School Decision Making. Review of Research in Education. 1991;17(1):225-266. doi:10.3102/0091732X017001225

45. Gillespie NA, Walsh M, Winefield AH, Dua J, Stough C. Occupational stress in universities: Staff perceptions of the causes, consequences and moderators of stress. Work Stress. 2001;15(1):53-72. doi:10.1080/02678370117944

46. Crosby KS. The Relationship Between Administrative Support And Burnout In Turnaround Schools. Dissertation. Eastern Kentucky University; 2015. Accessed October 21, 2020. https://encompass.eku.edu/cgi/viewcontent. cgi?article $=1353 \&$ context $=$ etd

FUNDING

There was no source of funding for this research.

AUTHORS' CONTRIBUTIONS

All authors contributed equally to this work. All authors read and approved the final manuscript.

PROVENANCE AND PEER REVIEW

Not commissioned; externally peer reviewed. 